\title{
Karakteristik Karkas Bandikut (Echymipera kalubu) di Kampung Wafmana, Distrik Mawabuan, Kabupaten Tambrauw
}

\author{
Carcass Characteristics Of Bandikut (Echymipera kalubu) In Wafmana Village, Mawabuan Distrik, \\ Tambrauw Regency
}

Piter Asiar, Frandz Rumbiak Pawere* dan Johan F Koibur

Fakultas Peternakan Universitas Papua, Manokwari

Jl. Gunung Salju, Manokwari Papua Barat

Article history

Accepted: September 23 2019 ;

Approved: August 1, 2019

* Corresponding author:

E-mail:

f.pawere@unipa.ac.id

\section{Abstract}

The research purpose to identify and investigate the carcass characteristics of bandicoot (Echymipera kalubu) in Wafmana Village Distric of Mawabuan Tambrauw Regency West Papua Province. Twenty indifidual of bandicoot ages \pm 4 month were used, consisted of of 10 ten individual males bandicoot and 10 individual females bandicoot. The research method was exploration. The results showed that body weight of males and females bandicoot were 1245,4 $\pm 484,38$ $\mathrm{g}$ and $710,95 \pm 252,27 \mathrm{~g}(\mathrm{P}<0,05)$. Carcass weight of males and females bandicoot were $1245,4 \pm 484,38 \mathrm{~g}$ and $710,95 \pm 252,27 \mathrm{~g}(\mathrm{P}<0,05)$. Carcass percentage of males and females bandicoot were 76,28 $\pm 6 \%$ dan betina $75 \pm 5$ $\%(\mathrm{P}>0,05)$. Weight cut fore quarter of males and females bandicoot were $580,86 \pm 245,72 \mathrm{~g}$ and $300,17 \pm 105,93 \mathrm{~g}(\mathrm{P}<0,05)$. Weight cut hind quarter of males and females bandicoot were $629,52 \pm 233,55 \mathrm{~g}$ dan $350,63 \pm 123,79 \mathrm{~g}$ $(\mathrm{P}<0,05)$. Fore Carcass percentage of males and females bandicoot were $45,98 \pm 2$ $\%$ and $42,63 \pm 4 \%(\mathrm{P}<0,05)$. Hind carcass percentage of males and females bandicoot were $50,98 \pm 4 \%$ and $49,53 \pm 4 \%(\mathrm{P}>0,05)$. There are differences in body weight, carcass weight, front carcass weight, rear carcass Weight, and the percentage of front carcass between male and female E. kalubu while there is no difference in the percentage of carcass and rear carcass percentage between male and female Echymipera.

Keywords: carcass characteristics, Echymipera kalubu

\section{Pendahuluan}

Potensi fauna di luar ternak konvensional yang telah dikenal dan memiliki potensi sebagai sumber protein hewani perlu digali dan diupayakan Pengembangan potensi sumber daya fauna merupakan sisi strategis bila dikaitkan dengan potensi unggulan di setiap daerah mengingat Indonesia sangat beragam baik secara geografis maupun sosial budaya. Papua adalah salah satu daerah di Indonesia yang memiliki keragaman jenis satwa yang tinggi. Keanekaragaman jenis satwa yang terdapat di Papua merupakan sumber plasma nutfah yang dapat dikembangkan untuk mencukupi kebutuhan manusia (Warsono, 2009)

Salah satu hewan marsupialia endemik yang sering dikonsumsi masyarakat Papua adalah bandikut (E. kalubu). Menurut situs resmi The IUCN red list of threatened species, E. kalubu memiliki status konservasi least concern atau sangat melimpah di alam. Daging bandikut telah lama dikonsumsi oleh masyarakat lokal sebagai sumber protein hewani dan secara budaya dapat diterima. Sebagai satwa sumber daging, bandikut memiliki laju reproduksi paling tinggi diantara semua marsupialia. Dalam setahun, seekor induk bandikut bisa melahirkan 5-6 kali dengan litter zise 2-4 ekor, lama bunting 12-13 hari dan lama menyusu 50-60 hari (Petocz, 1994). Bobot badan bandikut jantan berkisar 478-4600 gram dan betina 598-1500 gram tergantung umur dan jenisnya (Strahan, 1990; Flannery, 1995a dan 1995b; Warsono, 2009). Penelitian beberapa aspek biologis bandikut secara in-situ telah banyak dilakukan di Australia, sedangkan di Papua khususnya dan 
di Indonesia pada umumnya, informasi tentang bandikut masih sangat terbatas. Warsono (2009), menyatakan bahwa komposisi kimia daging bandikut $E$. kalubu adalah kadar air $72.42 \%$, protein $18.72 \%$, lemak $3,26 \%$, serat kasar 4,43\%, abu 2,53\% dan energi 1090 $\mathrm{kkal} / \mathrm{kg}$. selain itu Persentase karkas E. kalubu sebesar $67.8 \%$ dengan ratio daging tulang sebesar 3.41:1. Dari aspek warna, bau dan rasa daging bandikut dapat diterima khususnya oleh masyarakat Papua sehingga bandikut dapat dikembangkan sebagai satwa budidaya untuk tujuan produksi daging. Manfaat lain dari bandikut adalah rambut, tulang dan anak bandikut umur 12 hari dipercaya untuk pengobatan. Kusrini (2001) menyatakan Tingkat konsumsi daging bandikut rata-rata 60 gram per kapita per hari per musim berburu dan hasil perburuan antara 1-10 ekor/sekali berburu (Unenor, 2001). Sementara masyarakat memperoleh bandikut dengan cara berburu untuk perdagangan eceran dan konsumsi sehari-hari. Bandikut dijual di pasar hampir setiap hari dengan harga per ekor sebesar Rp 50.000 sampai Rp. 150.000,-

Masalah pemenuhan kebutuhan daging di Indonesia, khususnya di Papua dapat diatasi dengan cara memberdayakan potensi satwa lokal, termasuk bandikut. Bandikut salah satu hewan marsupialia yang sangat melimpah di alam Papua yang dapat dijadikan hewan harapan dalam pemenuhan protein asal hewani bagi masyarakat Papua karena memiliki persentase karkas sekitar 67,8 - 76\% dengan rasio daging tulang 3.41 : 1 (Warsono, 2009; Pawere, 2017). Selain itu populasi bandikut sangat melimpah di alam karena status konservasinya adalah least concern. Bandikut sering menjadi hama bagi manusia karena mengkonsumsi tanaman pertanian yang dibudidaya di kebun. Seperti singkong, keladi, betatas dan lain-lain.

Untuk mempertahankan keberadaan bandikut di alam dan sekaligus dapat memenuhi kebutuhan masyarakat akan daging salah satu upaya untuk melindungi dan mengembangkan satwa ini adalah pembudidayaan bandikut sebagai ternak pedaging. Sebagai kelanjutannya diperlukan tahapan penelitian untuk mengkaji potensi bandikut sebagai penyedia daging. Kajian tentang karakteristik karkas bandikut perlu dilakukan sehingga tersedia acuan untuk pemanfaatan dagingbandikut. Penguasaan terhadap sifat produksi tersebut dapat membantu dalam mengoptimalkan produktifitas bandikut. Hal ini pada gilirannya dapat memberi nilai tambah dalam rangka mengatasi masalah kebutuhan pangan asal hewan sekaligus pengembangan bandikut sebagai ternak budidaya (Warsono, 2009)

\section{Materi dan Metode}

Penelitian ini dilakukan selama 3 bulan, yaitu dari bulan Februari-April 2019 di Kampung Wafmana Distrik Mawabuan Kabupaten Tambrauw

\section{Materi}

Sebanyak 20 ekor bandikut yang terdiri dari 10 ekor jantan dan 10 ekor betina berumur sekitar 4 bulan digunakan dalam penelitian ini. Alat yang digunakan dalam penelitian ini adalah senter untuk berburu pada malam hari, timbangan duduk merk Weston kapasitas $2 \mathrm{~kg}$ graduation 10 gram, timbangan Prohex kapasitas $15 \mathrm{~kg}$ graduation 50 gram untuk menimbang bobot badan dan karkas bandikut, Pisau cutter digunakan untuk memotong bandikut, kamera untuk dokumentasi, parang untuk pembuatan jerat bandikut, sepatu boat untuk melindungi kaki selama di hutan, sarung tangan bedah dipakai selama pembedahan, tali nelon $3 \mathrm{~mm}$ dan nelon ukuran 40 dijadikan sebagai tali jerat, dan alat tulis menulis.

\section{Metode}

Penelitian dilakukan secara eksplorasi, dimana bandikut ditangkap dengan cara berburu mengunakan perangkap konvensional. Tahap Persiapan

Tahap persiapan meliputi beberapa langkah sebagai berikut:

1. Pengambilan data sekunder

2. Persiapan peralatan yang digunakan.

3. Penangkapan bandikut dengan cara membuat perangkap pada siang hari dan berburu malam hari.

4. Pengambilan data primer

\section{Tahap Pelaksanaan}

Tahap pelaksanaan penelitian meliputi beberapa langkah sebagai berikut:

1. Penangkapan bandikut dengan cara memasang perangkap pada siang hari dan beburu pada malam hari.

2. Penimbangan bobot hidup bandikut sebagai bobot potong $(\mathrm{g})$ 
3. Penyembelihan bandikut.

Penyembelihan bandikut dilakukan dengan cara memotong bagian leher dekat rahang bawah sehingga kulit, otot, vena jugularis, arteri karotis komunis, oesophagus dan trachea terpotong sempurna.

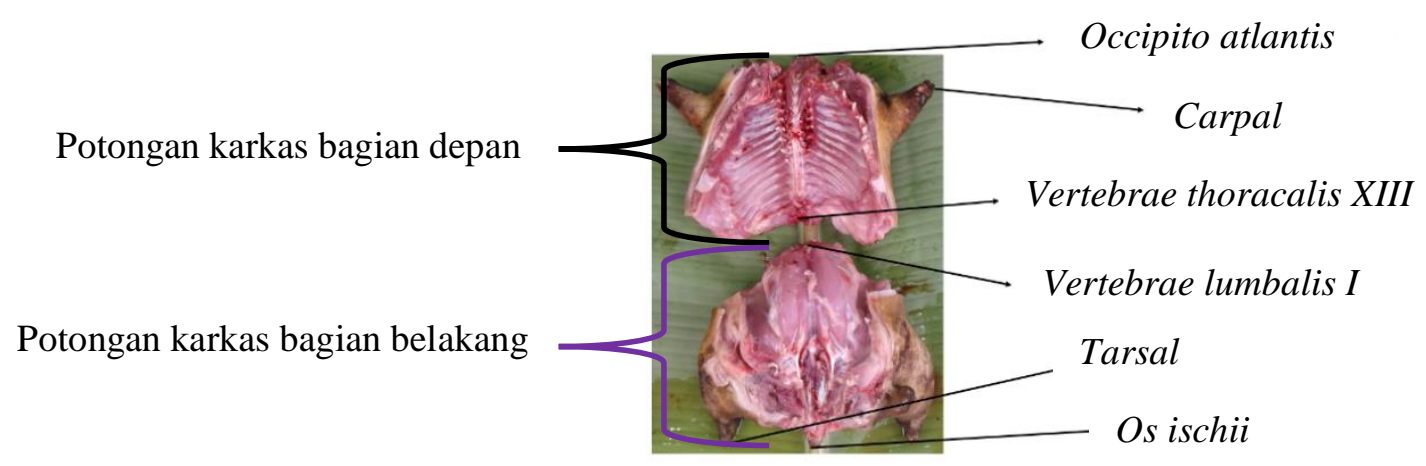

Gambar 1. Potongan karkas E. kalubu

4. Penghilangan bulu bandikut dengan cara dibakar

5. Pengeluaran isi rongga dada dan abdomen dengan cara menyayat diinding dada sampai anus kemudian isi rongga dikeluarkan.

6. Karkas segar yang diperoleh kemudian ditimbang untuk memperoleh bobot $\operatorname{karkas}(\mathrm{g})$.

7. Karkas segar dipotong menjadi 2 bagian utama, yaitu Karkas bagian depan dan belakang yaitu batas vertebrae thoracalis 13 dan vertebrae lumbalis 1.

8. Karkas depan dan belakang yang diperoleh kemudian ditimbang untuk memperoleh bobot karkas depan dan belakang (g).

Variabel yang diamati dalam penelitian ini adalah:

1. Bobot karkas (g): dapat dihitung dengan menimbang bandikut yang sudah dipotong yang dikurangi dengan darah, kulit, kepala, keempat kaki isi rongga dada, dan isi rongga perut.

2. Persentase karkas (\%) atau Dressing Precentage adalah rasio antara bobot karkas dengan bobot hidup waktu disembelih dikalikan dengan 100\%, atau dapat disederhanakan sebagai berikut (Santosa, 2010):

$\%$ Karkas $=\frac{\text { bobot } \operatorname{karkas}(g)}{\text { bobot potong }(g)} \times 100 \%$
3. Bobot potongan karkas bagian depan $(\mathrm{g})$, berat bagian karkas yang terdiri dari sepasang kaki bagian depan, dada, hingga tulang iga 13 .

4. Bobot potongan karkas bagian belakang $(\mathrm{g})$, berat potongan karkas terdiri dari vertebrae lumbalis 1, loin, paha hingga sepasang kaki bagian belakang.

\section{Analisis Data}

Data yang diperoleh dianalisis dengan independent sample-T test.

\section{Hasil dan Pembahasan}

Tabel 1 menunjukan bahwa rataan bobot potong kelompok jantan dan betina berturut turut adalah: $1602,5 \pm 571,37$ dan 936,1 \pm 309,12 . Bobot potong kelompok jantan lebih berat dibandingkan dengan kelompok betina $(\mathrm{P}<0,05)$. Diduga hal ini disebabkan oleh hormon androgen yang terdapat pada testis bandikut jantan. Androgen disintesis dan disekresikan ke dalam aliran darah dan sebagian besarnya membentuk testosteron. Setelah memasuki sel-sel targetnya, testosteron juga dimetabolisasi oleh aromatase membentuk estradiol di dalam hipothalamus dimana penentuan mental/seks sosial terjadi (Döhler, 1991), atau ia dimetabolisasi oleh 5 $\alpha$ reductase menjadi $5 \alpha$-DHT pada banyak organ-organ reproduksi jantan (Bruchovsky \& Wilson, 1968). Dihydrotestosterone (DHT) merupakan androgen alami yang berpotensial dan berperan sangat penting dalam 
mendeterminasi diferensiasi seksual, perkembangan organ-organ seks tambahan baik internal maupun eksternal serta berperan juga dalam perkembangan otot dan rambut pada sejumlah area (Tien-Min \& Chang, 1997). Testosteron berperan penting dalam menstimulasi tingkah laku psikoseksual (psychosexual behavior) dan perkembangan ductus Wolffii, otot, spermatogenesis, dan pertumbuhan (Imperato-McGinley et al., 1979). Warsono (2009) menyatakan bahwa bobot badan berkaitan erat dengan bobot karkas yang dihasilkan. Peningkatan bobot badan akan diikuti pula dengan meningkatnya bobot karkas. Menurut forest et al., (1975) dan Berg and Butterfield (1976), persentase karkas meningkat seiring dengan peningkatan bobot potong.

Tabel 1. Rataan bobot potong (g), bobot karkas (g), dan persentase karkas (\%)

\begin{tabular}{cccc}
\hline Kelompok bandikut & Bobot potong (g) & Bobot karkas (g) & Persentase karkas (\%) \\
\hline Jantan & $1602,5 \pm 571,37^{\mathrm{a}}$ & $1245,4 \pm 485,38^{\mathrm{a}}$ & $76,28 \pm 6^{\mathrm{a}}$ \\
Betina & $936,1 \pm 309,12^{\mathrm{b}}$ & $710,95 \pm 252,27^{\mathrm{b}}$ & $75 \pm 5^{\mathrm{a}}$ \\
\hline
\end{tabular}

$\overline{\mathrm{a}, \mathrm{b}}$ superskrip yang berbeda pada kolom yang sama menunjukkan perbedaan $(\mathrm{P}<0,05)$

Bobot karkas bandikut jantan dan betina juga berbeda (Tabel 1), dan terdapat perbedaan $(\mathrm{P}<0,05)$ rataan bobot karkas bandikut jantan dan betina berturut-turut sebagai berikut: $1245,4 \pm 484,38 \mathrm{~g}$ dan $710,95 \pm 252,27$. Haryoko dan Titik (2008), menyatakan bahwa komponen karkas terdiri dari daging, tulang dan lemak. Hasil penimbangan menunjukkan semakin besar bobot badan maka akan dihasilkan bobot karkas yang tinggi pula. Bobot karkas menjadi salah satu hal yang menarik dalam karakteristik karkas. Bobot karkas sangat tergantung dari bangsa bandikut dan pakan. Warsono (2009) menyatakan bahwa konsumsi bahan kering bandikut dipengaruhi oleh banyak faktor yang saling berinteraksi diantaranya aspek anatomi, status fisiologi, bobot badan, kandungan nutrisi, dan palatabilitas. Diduga bandikut mengkonsumsi pakan sangat dipengaruhi oleh beberapa faktor seperti komposisi kimia, jumlah kalori, bentuk fisik, palatabilitas, jumlah dan variasi makanan, bobot tubuh dan kondisi fisiologis yang baik.

Tabel 1 juga menunjukan bahwa persentase karkas bandikut jantan 76,28\% dan betina $75 \%$ tidak berbeda $(\mathrm{P}>0,05)$, tetapi masih lebih tinggi dibandingkan dengan persentase karkas hewan lainnya seperti yang terlihat pada Tabel 2.

Peningkatan sedikit ukuran tubuh dapat menyebabkan peningkatan secara proporsional dari bobot tubuh suatu ternak (Rao et al., 1978). Hasil penghitungan persentase karkas sejalan dengan hasil pengukuran terhadap bobot potong (bobot hidup) dan bobot karkas karena persentase karkas merupakan perbandingan antara bobot karkas dengan bobot hidup saat dipotong (dikurangi isi saluran pencernaan dan urin) dikali dengan $100 \%$ (Santoso dan Sutarno, 2010). Bobot potong mempengaruhi persentase karkas yang dihasilkan. Sumardianto dkk, (2013), menyatakan bahwa semakin tinggi bobot potong maka pesentase karkasnya semakin tinggi pula.

Kenyataan tersebut memberikan indikasi bahwa bandikut berpotensi untuk dijadikan sebagai hewan alternatif penghasil daging. Menurut Williamson and Payne (1993), pada umumnya satwa liar menghasilkan karkas dengan persentase lebih tinggi.

Tingginya persentase karkas kelompok jantan dibandingkan dengan betina diduga disebabkan oleh bobot awal individu yang kemungkinan lebih berat. Rizqiani (2011),menjelaskan bahwa ketika bobot awalnya lebih tinggi maka memungkinkan hasil bobot akhirnya lebih tinggi juga. Sumardianto dkk, (2013), menyatakan bahwa semakin tinggi bobot potong maka pesentase karkasnya semakin tinggi pula.

Hasil penelitian terhadap bobot karkas, bobot potongan karkas bagian depan, bobot potongan karkas bagian belakang, persentase karkas bagian depan, dan persentase karkas bagian belakang pada bandikut berdasarkan jenis kelamin disajikan pada Tabel 3 dibawah ini. 
Tabel 2. Persentase karkas bandikut dan beberapa jenis ternak/hewan lain (\%)

\begin{tabular}{|c|c|}
\hline Jenis hewan & Rataan \\
\hline Bandikut & $76,28 \pm 6$ \\
\hline Tikus hutan ${ }^{1}$ & $57,67 \pm 1,15$ \\
\hline Tikus budidaya $^{1}$ & $62,19 \pm 3,62$ \\
\hline Kancil $^{2}$ & 52,03 \\
\hline $\mathrm{Napu}^{3}$ & 59,31 \\
\hline Sapi Madura ${ }^{4}$ & $46,88 \pm 1,34$ \\
\hline Sapi Bali ${ }^{4}$ & $53,61 \pm 0,82$ \\
\hline Sapi Sumba Ongole 4 & $43,62 \pm 1.32$ \\
\hline Kambing kacang 5 & 42,46 \\
\hline Kambing $\mathrm{PE}^{6}$ & 46,65 \\
\hline $\operatorname{Domba}^{7}$ & 52,00 \\
\hline $\mathrm{Babi}^{7}$ & 72,00 \\
\hline Ayam pedaging $^{8}$ & 71,25 \\
\hline
\end{tabular}

Tabel 3 bahwa semua variabel yang diamati : bobot karkas, potongan karkas bagian depan, potongan karkas bagian belakang dan persentase karkas bagian depan menunjukkan perbedaan nyata $(\mathrm{P}<0,05)$ kecuali persentase karkas bagian belakang yang sama. Hasil penelitian ini sama dengan penelitian Warsono (2009) yang menyatakan bahwa potongan karkas kaki belakang bandikut lebih besar dari potongan karkas kaki depan terhadap bobot karkas yaitu sebesar 215,10 dan 154,66 g. Dari penelitian ini juga ternyata bahwa bobot potongan karkas bagian belakang lebih besar dibanding bobot potongan karkas bagian depan baik untuk kelompok jantan maupun betina. Selain itu juga karkas bandikut pada potongan bagian belakang lebih berat dari pada potongan karkas pada bagian depan. Oleh karena itu, dapat disimpulkan bahwa dari sisi komersial daging bagian belakang bandikut lebih berat dibandingkan dengan bagian depan sehingga menjadi salah satu bahan pertimbangan konsumen.

Tabel 3. Rataan persentase karkas, potongan karkas bagian depan, potongan karkas bagian belakang, persentase bagian depan, dan persentase bagian belakang bandikut jantan dan betina

\begin{tabular}{lccccc}
\hline $\begin{array}{c}\text { Kelompok } \\
\text { Bandikut }\end{array}$ & $\begin{array}{c}\text { Bobot } \\
\text { Karkas }\end{array}$ & $\begin{array}{c}\text { Potongan } \\
\text { Karkas } \\
\text { Bagian Depan }\end{array}$ & $\begin{array}{c}\text { Potongan } \\
\text { Karkas Bagian } \\
\text { Belakang }\end{array}$ & $\begin{array}{c}\text { Persentase } \\
\text { Bagian Depan } \\
(\mathbf{g})\end{array}$ & $\begin{array}{c}\text { Persentase Bagian } \\
\text { Belakang (\%) }\end{array}$ \\
\hline Jantan & $1245,4 \pm 485,38^{\mathrm{a}}$ & $580,86 \pm 245,72^{\mathrm{a}}$ & $629,52 \pm 233,55^{\mathrm{a}}$ & $45,98 \pm 2^{\mathrm{a}}$ & $50,98 \pm 4^{\mathrm{a}}$ \\
Betina & $710,95 \pm 252,27^{\mathrm{b}}$ & $300,17 \pm 105,93^{\mathrm{b}}$ & $350,63 \pm 123,79^{\mathrm{b}}$ & $42,63 \pm 4^{\mathrm{b}}$ & $49,53 \pm 4^{\mathrm{a}}$ \\
\hline
\end{tabular}

a,b superskrip yang berbeda pada kolom yang sama menunjukkan perbedaan $(\mathrm{P}<0,05)$

\section{Kesimpulan}

Terdapat perbedaan bobot potong, bobot karkas, potongan karkas bagian depan, potongan karkas bagian belakang, dan persentase karkas bagian depan antara $E$. kalubu jantan dan betina sementara tidak terdapat perbedaan pada persentase karkas dan persentase karkas bagian belakang antara $E$. kalubu jantan dan betina.

\section{Daftar Pustaka}

Arifin. 2004. Kajian Produktifitas Dan Produk Napu (Tragulus Napu) Di Provinsi Jambi 
Disertasi. Sekolah Pascasarjana, Universitas Padjadjaran, Bandung.

Berg RT, And RM. Butterfield.1976. New Concepts Of Cattle Growth. Sidney University Press, Sidney.

Boggs DL, Merkel RA. 1984. Live Animal Carcass Evaluation and Selection Manual. $2^{\text {nd }}$ Ed. Kendall/Hunt Publishing Company, Iowa.

Bruchovsky, N. And J.D. Wilson. 1968. The Conversion of Testosterone to 5 Androstan-17 -Ol-3-One by Rat Prostate In Viwo and In Vitro

Damshik M. 2001. Produktivitas Kambing Kacang yang Mendapat Ransum Penggemukkan dengan Kandungan Protein yang Berbeda. Disertasi. Sekolah Pascasarjana, IPB, Bogor.

Flannery T. 1995a. Mammals of New Guinea. The Australian Museum.

Flannery T. 1995b. Mammals Of The South West Pacific and Moluccan Islands. The Australian Museum.

Haryoko. I. dan Titik Warsiti. 2008. Pengaruh Jenis Kelamin dan Bobot Terhadap Karateristik Fisik Karkas Peranakan New Zealand White. J Animal Production 2(10): $85-89$.

Imperato-McGinley, J., E.P. Ralph ., T. Gautier. and E. Sturla. 1979. Androgens and the Evolution of Male-Gender Identity among Male Pseudohermaphrodites with $5 \alpha$-Reductase Deficiency. N Engl J Med. 300: 1233-1237.

IUCN Red List, http://Www.Iucnredlist.Org/ Details/7018/0. [20 Mei 2016]

Kusrini DS. 2001. Tingkat Konsumsi Daging Bandikut oleh Penduduk Asli dan FaktorFaktor yang Mempengaruhinya di Kecamatan Warmare. Tesis. Sekolah Pasca Sarjana. Universitas Papua. Manokwari.

Pawere F. R. P.2017. Produktifitas Bandikut (Echymipera kalubu) Sebagai Hewan Harapan dalam Pemenuhan Gizi Masyarakat Papua. Prosiding Seminar Nasional Hilirisasi dan Massalisasi Inovasi Teknologi Spesifik Lokasi Mewujudkan Papua Sebagai Lumbung Pangan Indonesia Berorientasi Ekspor. 17 November 2017. Jayapura. Hlm 148-153

Petocz R. 1994. Mamalia Darat Irian Jaya. Penerbit Gramedia Pustaka Utama. Jakarta.
Rao,. D. R, Sunki G.R, Johnson W.H, Chen C.P. 1978. Effect of Weaning and Slaughter Age on Rabbit Meat Productions II.Carcass, Quality and Composition. J Animal Sci 5: 578-582.

Rizqiani. 2011. Performa Kelinci Potong Jantan Lokal Peranakan New Zealand White yang diberi Pakan Silase atau Ransum Komplit.

Rose SP. 1997. Principles of Poultry Science. London : CABI International.

Rosyidi D. 2005. Beberapa Aspek Biologi dan Karakteristik Karkas Kancil (Tragulus javanicus). Disertasi. Sekolah Pascasarjana IPB, Bogor.

Santoso, U dan Sutarno. 2010. Bobot Potong dan Karkas Kelici New Zealand White Jantan Setelah Pemberian Ransum Kacang Koro (Mucuna Pruriens Var. Utilis). Bioteknologi. 7(1):19-26.

Strahan, R. 1990. The Australian Museum. Complete Book of Australian Mammals. The National Photgraphic Index Of Australian Wildlife. Angus and Robertson Publishers.

Sumardianto. T. A., P. Endang dan Masykuri. 2013. Karateristik Karkas Kambing Peranakan Etawa dan Kambing Kejabong Jantan Pada Umur Satu Tahun. J. Animal Agriculture. 1(2) :175 - 182.

Tien-Min, L. and C. Chang. 1997. Cloning and Characterization of TDD5, an Androgen Target Gene That Is Differentially Repressed by Testosterone and Dihydrotestosterone. Proc. Natl. Acad. Sci. USA., 94: 4988-4993.

Unenor E. 2001. Teknologi Perburuan Bandikut oleh Suku Hatam di Oransbari. Tesis. Sekolah Pascasarjana Universitas Papua. Manokwari.

Wahyuni I. 2005. Tingkah Laku, Reproduksi, dan Karakteristik Daging Tikus Ekor Putih (Maxomys hellwandii). Disertasi. Sekolah Pascasarjana IPB, Bogor.

Warsono IU. 1994. Evaluasi Performa Karkas dan Daging Beberapa Bangsa Sapi Lokal (Madura, Bali, dan Sumba Ongole). Tesis. Program Pascasarjana, Universitas Padjadjaran. Bandung.

Warsono IU. 2009. Sifat Biologis dan Karakteristik Karkas dan Daging Bandikut 
(Echymipera

kalubu).

PascaSarjana IPB, Bogor.

Williamson G and Payne WJA. 1993.

Pengantar Peternakan di Daerah Tropik.
Gadjah Mada University Press, Yogyakarta. 